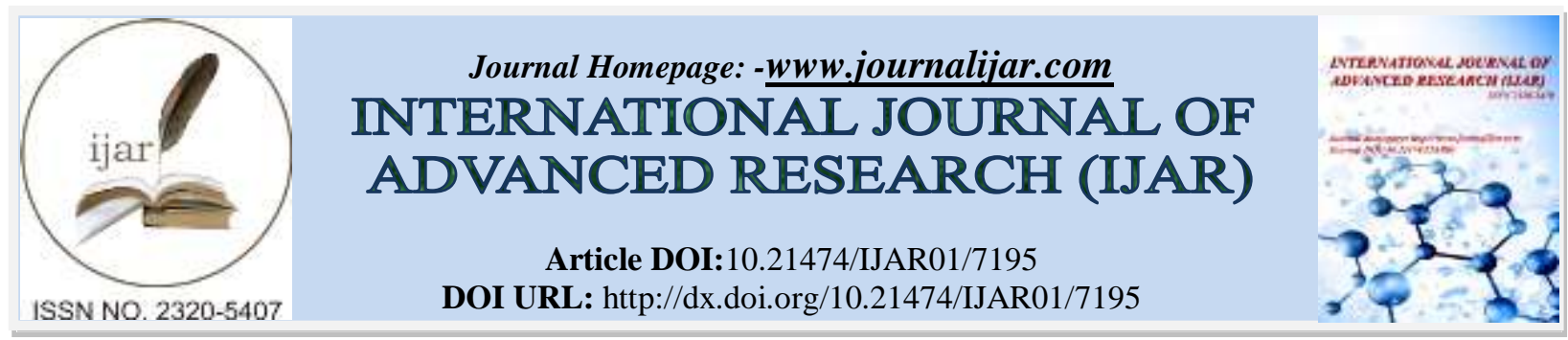

RESEARCH ARTICLE

\title{
AL-SAYYID MIN ḤAQL AL-SABĀNIKH: PERSONAL FREEDOM VERSUS MECHANICAL SYSTEM.
}

Eisam Asaqli and Mariam Masalha.

The Academic Arab College For Education In Israel, Haifa.

\section{Manuscript Info}

Manuscript History

Received: 03 April 2018

Final Accepted: 05 May 2018

Published: June 2018

Key words:

Arabic Science Fiction,

Characterization, Mechanical System,

Robots, Rebellion, Personal Freedom.
[........................

\section{Abstract}

This study deals with the issue of conflict between the programmed mechanical system and the rebellious human being against this system as reflected in the science fiction novel al-Sayyid min Haql al-Sabānik (The Mister from the Spinach Field) by the Egyptian writer Șabrī Mūsā. The novel describes a society divided into classes, committees, centers and bodies run by a general system, which establishes a fixed daily program for everyone from the moment each person rises until they go to bed. Thus, the mechanical robotic human being becomes the master of the universe, while the real human being turns into a mechanical slave that obeys and performs without thinking. The hero of the novel, Homo, tries to break this programmed track because it nullifies citizens' creativity, negates their personal freedom within the concept of 'discipline', and prevents them from following their whims. The tragedy of Man in the coming age lies in his acceptance of slavery imposed by the programmed system, while any attempt to escape it will be abortive and lead to loss and frustration.

Copy Right, IJAR, 2018,. All rights reserved.

\section{Introduction:-}

al-Sayyid min Haql al-Sabānikh: Synopsis of the Novel:-

Șabrī Mūsā's novel al-Sayyid min Haql al-Sabānikh (The Mister from the Spinach Field) ${ }^{1}$ is a science fiction (SF) novel. ${ }^{2}$ It depicts human society in the year of 2481, following several centuries of imagined technological

1. The novel appeared in the Egyptian magazine Șabāh al-Khayr in consecutive chapters from September 1981 January 1982 (18 chapters). It was republished as a novel in an independent book in 1987, and reprinted in a second edition in 1994, and in a third edition in 1997. For more details about SF in Arabic, see: Barbaro, 2013; Snir, 2000; Snir, 2002.

2. SF has proved notoriously difficult to define. It has been explained as a combination of romance, science and prophecy; as a genre based on an imagined alternative to the readers' environment; and as a form of fantastic fiction and historical literature. It has also been argued that SF narratives are the most engaged, socially relevant, and responsive to the modern technological environment (Seed, 2011: 1-2). The Oxford English Dictionary defines SF as imaginative fiction based on postulated scientific discoveries or spectacular environmental changes, frequently set in the future or on other planets and involving space or time travel', adding that the term did not come into common usage until the 1920s. Adam Roberts views the terms of this basic dictionary definition are instructive: 'imaginative fiction' differentiates SF from 'realist' fiction, in which there is some attempt at a literary verisimilitude that reproduces the experience of living in the world we recognise as ours 
progress. $^{3}$ The novel describes a society divided into classes, committees, centers, institutions and organizations and controlled by the General System. ${ }^{4}$ The events of the novel take place in a quarter of Earth's southern hemisphere, which is all that remains of the world's population after the first electronic war. In this war, people used everything that was available and at hand such as weapons, atomic and nitrogen bombs, whose radiation burnt and melted, destroying human civilization. ${ }^{5}$ The events of the novel revolve around the refusal of its protagonist, Homo, to follow his daily life program - a programmed and formatted mechanical life that is precision-planned, with strict discipline and control. For example, he stops coming back home after work in the spinach field, instead roaming around the streets. In the end, he has to stay overnight outside, in order to enter with the other workers when the work starts in the spinach field in the morning.

The Center of Mechanical Investigation calls him in for questioning regarding his absence from work and refusal to go back home that night. They discuss Homo's issue of spending his time at Public Debate Amusement Centers, where he meets a person called Proof. Homo and Proof establish an opposition front against the mechanical system, which destroys the individual abilities and talents of men. In response to the repeated absence from work and disobedience to the System, the System drafts a revolutionary plan comprising four points, and presents it for a public referendum:

1. Anyone who opposes the system will be treated chemically by injecting some kind of chemical compound into the cells of his or her nervous system;

2. His or her marriage will be annulled until the individual's anti-social feelings are eradicated and his or her being is diverted towards human society as a whole;

3. Fertility is no longer an issue and pregnancy is to be abolished. Delivery-plants, where delivery is conducted through tubes, will be established in order to suppress and remove individual feelings towards one's own baby;

4. Houses are to be abolished and substituted with free hotels; thus, the instincts of individual property will be destroyed and the human being becomes free.

The referendum is held and the majority vote for the program. Proof attacks this plan, and calls the people to return to the real Earth below their enclosed zone and Nature. The System's delegate tells them that return to the Earth and Nature is tantamount to a decision to commit suicide and die a slow death. Proof and his group, including Homo, insist on going back to Earth. The System prepares special equipment to transfer and protect them. The System also vaccinates them against diseases and suspends their anti-virility vaccination, so that their potency will return to them and they will be able to give birth to children again. Finally, the gate is opened to them to go out.

As the group wanders in the unknown wastelands, they are exposed to different kinds of dangers. On the third day, Homo himself reconsiders his actions and realizes that he was mistaken and his understanding flawed. On the fourth day, he returns home alone and asks to reenter the compound. Homo stands broken in front of the entrance gate,

(Roberts, 2000: 2). Darko Suvin defined SF as 'a literary genre whose necessary and sufficient conditions are the presence and interaction of estrangement and cognition, and whose main formal device is an imaginative framework alternative to the author's empirical environment.' (Suvin, 1979: 8-9). Damien Broderick concludes that the SF is a 'species of storytelling native to a culture undergoing the epistemic changes implicated in the rise and supercession of technical-industrial modes of production, distribution, consumption and disposal.' (Broderick, 1995: 155). For a listing of other definitions of SF, see Wolfe, 1986.

3. It is worth mentioning that the events in many of SF novels in Arabic literature take place in the future, tens or hundreds of years in the future. See, for example: al-Subāt al-jalīd 1993 and al-Khurūj min al-jahīm 1994 by Ṭālib 'imrān and al-Mārid al-Ma 'dañ̄ 1981 by Ra' ūf Wașfì. Andy Sawyer sees that despite some notable precursors, such as Mary Shelley's The Last Man (1826) and Jane Webb Loudon's The Mummy! (1827), the imagination of fictional futures only begins to become commonplace toward the end of the nineteenth century as SF crystallizes out of post-Romantic secular apocalypse and utopian speculations (Sawyer, 2009: 490). For more details about Futurology in SF, see Butler 2014, and for more details about Future History in SF, see Sawyer, 2009.

4. It is worth mentioning that some Western SF novels describe societies that are similar to this one. See, for example Brave New World (1931) by Aldous Huxley, in which The World State is a benevolent dictatorship headed by ten World Controllers. See, also, This Perfect Day (1970) by Ira Levin.

5. According to Aris Mousoutzanis, SF is often considered to be the dominant $20^{\text {th }}$ medium for the expression of visions of apocalypse and catastrophe, something that might seem paradoxical for a genre originally associated with ideas of scientific progress and technological utopianism (Mousoutzanis, 2009: 458). 
knocks on the thick glass with a stone and cries out, asking for someone to open the gate, but no one answers him or responds to his call, and thus he stays outside (Mūsā, 1987).

\section{The novel's place in the history of Arabic SF:-}

The novel, considered one of the most important SF novels in the Arab world, constituted a new and innovative approach in Arab novel writing, differing from the conventional Arab novel in three ways. ${ }^{6}$ First, it offers a new artistic structure by being set in a future utopian state. Mūsā extrapolated from the technological developments of his day to construct a utopian world run by a general system consisting of committees of experts. In this system, people live happily, enjoying its affluence and luxury through attainment of social justice. Second, Mūsā introduced new themes: intellectual issues and new subjects previously not dealt with in conventional Arabic novels. Such topics include test-tube babies, chemical feeding through tubes, lengthening the average age of life (to reach 150 years), free housing, being taught by speaking books, marriage dictated by the system's requirements, no surveillance and secret police as a result of society being crime-free, and transportation by rockets and spaceships. ${ }^{7}$ In addition, the novel introduces philosophical propositions such as man's desire to be engaged in manual work rather than scientific work, and intellect versus instincts. Third, the novel tries to achieve four objectives:

1. Predicting the future and man's fate four centuries hence. At the same time, it warns us of what is waiting for us in a new, changing and developing world - if humanity adopts a scientific method that harms us by making men into the slaves of machines. At the same time, the novel refers to ways of survival, and cultural prosperity.

2. Warning us to reconsider where our world is headed. By constructing a utopia in the age of science, the novel hopes to expose its cruel side, challenging us to try to change today's reality so that we avoid the future depicted in the book.

3. Criticizing current society by presenting a contradictory image to it, or introducing a substitute for it. The novel is a masked satire that describes a utopian society in order to censure modern society, describe the areas where corruption, decay and imbalance prevail, or to compare present society and utopian society.

4. The novel makes the reader understand the world and see the unknown in it. It also increases his awareness of himself and his historical and cultural position in the era of technology.

\section{Homo: The Rebel:-}

Characterization is the process by which the author reveals the personality of a character. There are two ways an author can convey information about a character. 1. Direct Characterization (Explicit), 2. Indirect Characterization (Implicit). In direct characterization, the author tells the audience about the personality of the character directly. He or she may do this via the narrator, another character or by the character him- or herself. Indirect characterization shows things that reveal the personality of a character. There are different methods of indirect characterization: speech, dialogue, thoughts, actions, looks, physical appearance, characters' name, places, nature, mannerisms and

6. Ada Barbaro believes that the father of the SF in Arabic is Nihād Shariff (1932-2011), an Egyptian writer who passed away not long ago. His novel Qāhir al-Zaman (Victory of Time) is considered a milestone in the production of SF. There are many other writers who - although they did not dedicate themselves entirely to this genre - at some point they did have a short SF period; e.g., the Egyptian author Șabrī Mūsā who wrote a dystopia (al-Sayyid min Haql al-Sabānikh), a theme which actually was born with him in Arabic literature. See Barbaro 2013 (interview with Ada Barbaro). A dystopia or anti-utopia refers to a world that is worse than our current world. What prevails in a dystopia is chaos, absence of the rule of law, absence of human values and principles, control of the machine over human beings, suppression of liberties and individual freedom, and above it all, a dictatorship. Dystopia, also, expresses people's fears about the future as a result of extreme over-dependence on scientific progress and technology. Dystopian SF also intersects with other subgenres of SF, such as alternate artificial intelligence, post-apocalyptic worlds, cyberpunk, and dying earth fiction. Other well-known novels in the genre include Brave the New World by Aldous Huxley, Nineteen Eighty-Four by George Orwell, Do Androids Dream of Electric Sheep? by Phillip K. Dick, and Cloud Atlas by David Mitchell. For more details about utopias and anti-utopias in SF, see James, 2003: 219-229.

7. Barbaro (2013) believes that SF is a genre that both attracts attention and curiosity and breaks the still existing stereotypes about the Arab world. Through SF, many of Islamic society taboos such as sex are broken. For example, al-Sayyid min Haql al-Sabānikh by Șabrī Mūsā is actually a dystopia. The writer deals with sex and though he is quite explicit, a careless reader would not say that this book is about sex. Mostly, writers who write about SF dystopias are criticizing their society harshly. See, for example, the SF short story Fī Sanat Milyūn by Tawfīq al-Hakīm. 
interaction with other characters, including other characters' reactions to that particular person. The audience must infer for themselves what the character is like through these methods. ${ }^{8}$

The author of al-Sayyid min Haql al-Sabānikh depicts Homo's rebellious character against the System through various techniques: The character's name, the relationship of the character with the place and nature, the dialogue between the character and other characters. ${ }^{9}$ The author employes these techniques so that Homo's image in the reader's mind would be complete in all its aspects. The reader would see his loss of will, slavery to the robots/machines, inability to see beauty or hear the call of nature, loss of the desire to search for purpose in life, loss of exposure of human intelligence to danger, transformation of human beings into similar copies of each other. The author introduces these aspects successfully, through Homo's meeting with the investigation committee, his arguments with his wife and friends, and his search for understanding of his psychological condition.

\section{The Character's Name:-}

The author's choice of names for his characters evoke various assocations, dimensions and intentions in order to arouse and provoke the receiver/reader mind. A character's name completes the picture of the character's image and features. An author chooses his characters' names to accord to his or her artistic considerations and having, of course, full understanding of the narrative work (Bahrāwī, 2009: 247; Hamdāwī, 2010). Philippe Hamon (1972) believes that the proper noun is the main clue to the character, because it reveals the character's attributes and its semiotic components, and eases the mission of reading.

The modern character has lost the role that it played in the classical novel. Some novelists tend to eliminate the landmarks of 'character' by depriving it of its name, its physiological dimensions, and its history in general. Other turn it into a pronoun, a first person speaker, a mere 'voice' with no role (al-Bārdī, 1993: 213-215). Some critics hold the view that many writers in the $20^{\text {th }}$ century spoke of the 'death of the character'. Roland Barthes (1974: 95) argues that what is coming to an end in contemporary novel is the character, and the thing that can no longer be written is the proper noun. Mạ̣mūd Mạ̣mūd (1983: 133) sees that some SF writers are interested in the idea or the general image of Man, which pushes them to sacrifice characterizations. Therefore, SF characters are not distinguishable from each other or are not unique in specific particular features, because the character is nothing but a representative of a human being. Characterization in SF barely distinguishes between male and female characters, because the individual is nothing but a type or model of the human race. ${ }^{10}$

The author of al-Sayyid min Haql al-Sabānikh deprives his characters of their proper names, and labels them using symbols, which implies that the characters represent ideas that the writer is disseminating through the novel as well as stand for certain groups in society. He chooses names for his characters that have specific definitions and imply something about humankind, rather than giving them names that allow them to be separate individuals ('Abdullāh, 1989: 26). Names are chosen according to artistic and esthetic considerations and so that they fit the characters' roles and actions. The meaning of the Latin word "Homo" is "human being"—which, in this novel, applies to any human being in the $25^{\text {th }}$ century, when all human beings are similar to each other. The author also refers to Homo with the title of "al-Sayyid / the Mister" through the novel's seven chapters to emphasize the symbolic meaning of his 'mastery'. Homo also represents a general model for the human beings that will exist in the $25^{\text {th }}$ century, as if, after giving him the general dimension, the writer dedicated the specific name 'Homo' to him, which underscores the general name itself ( $\mathrm{i} d, 1985: 225)$.

Homo represents the man who is rebelling against the mechanical System that is killing the creative feelings of individuals, and personal freedom, preventing individuals from having impulses of their own and hindering their

8. For more details about characterization in literature, see Docherty, 1983; Fokkema, 1991; Garvey, 1978; Scholes, Phelan and Kellogg, 2006: 160-206.

9. Mark Siegel sees that SF novels often tend to portray their fictional worlds through the subjective perception of their characters, described in realistic fashion; television SF, in contrast, tends to use more stereotypical, stylized characters and to emphasize the action-oriented plot and its mythic, allegorical, or symbolic overtones (Siegel, 1980).

10. According to Helen Merrick, traditionally, SF has been considered a predominantly masculine field, which through its focus on science and technology, 'naturally' excludes women, and by implication, considerations of gender. To varying degrees throughout its history, SF has in fact functioned as an enormously fertile environment for the exploration of sociocultural understandings of gender (Merrick, 2003: 241). 
imagination, from which creative genius, is born from developing. The mechanical man (Robot) in the novel becomes 'master of the world' and the human being becomes a slave to what the mechanical man introduces. ${ }^{11}$ Finally, all things, relations and feelings turn into a programmed moment in this comprehensive mechanical context.

Scientific development in the future, according to this novel, has reached the point where it can create the means of destruction and programming of human beings. Humans are merely a wart or pimple on the face of the machine and computer. This situation influences the events, the characterization, and the conflict to such a point that the reader sees the turning of the character into a 'type' or 'symbol'. The human has turned into a 'number' as the System eliminates his feelings. Therefore, the characters' behavior and their habits become identical, indistinguishable from each other, having no unique qualities. It is enough to know one individual, in order to know the other characters, i.e., the rest of the numbers. al-Sayyid/Mister Homo's number is (7049), and his wife's number is the same. His friends are numbers and all their relationships are industrial (al-Jayyār, 1987: 86-89; Raḍā̄n, 1987: 20; 'īd, 1985: 225; Mūsā, 1987: 39-42). ${ }^{12}$

Homo's fate was tragic because he forgot that time does not go in reverse. The apparatuses of the general System are able to turn Mister Homo and his companions into experimental tools to find out the effect of life in a deserted land. They are 'samples' or 'specimens' - not ordinary people. The characters are submissive characters subject to the authority and control of the writer, and - within the text - the control of the machine. Here, the world is encoded; the characters turn into symbols of the ideas that the writer wishes to disseminate through them. This symbolic coding starts with the characters' names, and moves to their function. The name of the hero, Homo, means human being, but the other characters have different types of symbolic names. This naming supports the symbolic encoded "thingness" of the characters, which reflects the writer's deliberate abstraction and the dominance of the idea over characterization (al-Jayyār, 1987: 93-95).

\section{Place:-}

Place in novel is an essential element in the structure of the characters. Further, it does not exist until its penetration by the characters, with their characteristic features, and the events that they initiate. This process confirms that Place is a reality that is lived, and it affects human beings to the same degree that they affect it. This relationship is most intense when Place plays a part in the formation of the character, because characters cannot be completed by themselves alone. As they encounter the world around them, they grow and are affected by everything around them as well as project their cultural values onto the place around them (Bachlard, 1994: 3-38; Lotman, 1977: 217-231). The relationship between the place and its residents is reciprocal and strong. The imprints and features that the place leaves on its residents cannot be changed or easily or quickly erased (al-Qāsim, 2005: 119). Patrick Murphy (2009: 374) limits the meaning of environment to the setting or locale surroundings, which includes the natural, the cultural, and the artificial. Much of SF takes place in manufactured environments, and some in natural environments, including the human body. The environment consists of the surroundings with and within which characters interact, but they themselves are usually represented as existing apart from this environment.

This novel confronts its readers with a mental-dreamy vision that attempts to form a new world in which the earth and the sky trade places with each other, and in his utopian vision, the writer builds up within the world of space, a world that is based on modern advanced scientific foundations. This world has several closed spaces: the spinach field, the investigation hall, the couple's room, the friend's room, the meeting place of free love, and the debate hall, alongside the narrow capsules used for travel and transportation. The writer confines his characters and we his

11. A robot (from the Czech robota) is a worker. In Karol Čapek's play, R.U.R. (1920), from which this name derives, mechanical men are created as workers, but become so competent that they supplant their masters. Perhaps the most visually definitive robot was Robby, the metal-box-bodied, goggle-eye good servant in the 1956 film Forbidden Planet; but it was Isaac Asimov, in a series of short stories published between 1950 and 1977, who developed the concept of thinking robots (Roberts, 2000: 159).

12. Scott Sanders noticed that lot of novels written by Western writers such as Isaac Asimov, Brian Aldiss, John Bruuner, and Ira Levin introduce governmental institutes that deal with people as numbers and digits within grids, tables, and graphs. What characterizes the people in these novels is their similarity, homogeneity, and loss of identity; see Sanders 1979: 135-136, and, for example, Ira Levin's This Perfect Day (1970). The latter novel describes a world managed by a central computer called UniComp, which determines the behavior of all people, observes every person, and locates his place at any time it likes. Every person has a number, and the hero's number is Li RM35M4419. 
readers in this narrow place and uses television technology and broadcasting as the means for connecting and communicating. Thus, he breaks the barrier of place and time, using science and transcending the limitations of time and place (al-Jayyār, 1987: 84-85, 97-98). ${ }^{13}$

The life of Mister Homo is limited to specific places that the general System has planned and programmed. Homo and others are prevented from going anywhere else. Homo works in the Field of Spinach, which is also called the 'Field of Optic Cultivation', though he does not like spinach. Homo's journey is a daily perfectly programmed journey that takes him from his apartment to the spinach field and back. Every morning, Homo finds himself in a crowded queue of people entering the spinach field. After work ends, he gets into the car and shuts the capsule, and precisely ten minutes later, the car stops in mid-air, and the capsule in which he sits is launched. It lands on the high tower, which is his residence complex. Then, the lift takes him up to his apartment, where he continues his boring life - with which he has become dissatisfied. His wife returns from work, prepares tea for him, and tells him her news. Then, they make love until it is time to watch the play on TV. They switch on the TV and watch the play for an hour. After that, they watch the latest news of the world. The broadcast stops, the electricity is switched off, and there is no more light. It is time to go to bed, and after five minutes, he sleeps unwillingly (Mūsā, 1987: 9-11). ${ }^{14}$

Homo wants to break away from this programmed track because it is a boring, gloomy one. Homo sees that his daily life is depressing because it is a mechanical life designed in an extremely precise way, with very strict discipline. Without the few minutes when he walks from the field to the car park, and from his capsule to the roof tower, to the lift, and through the halls to his apartment door, his bones would freeze and stiffen like wood. When he finds himself in the queue of workers, his heart pounds and he wishes to escape his heavy daily program. Therefore, Homo moves off from the queue that leads to the field of spinach until he is away from it. To his surprise, he feels that his feelings of distress have dissipated, and comfort enters his soul. At this instant, he begins to enjoy the moment - an instance that has not been programmed - and continues running in the broad yard laughing with joy, pleasure and happiness, jumping and waving his arms and legs in the air (Mūsā, 1987: 11-14, 46).

The System's representatives summon Homo for an investigation. They discuss his issues and through this discussion, Homo's character and the character of the System's representatives are revealed. The representatives of the System see that Homo's condition is similar to the old condition from which ancient people used to suffer. Those people appear in the movies in the cinema archive, sometimes shown on television in order to entertain contemporary citizens with the strange life that their ancestors used to live in the $20^{\text {th }}$ century and what followed it. Based on what they see, the representatives of the System want to know what has happened to Homo psychologically and what has made him behave in this uncontrolled way so that they can treat him chemically. When Homo is asked about his mental breakdown and what made him behave in an undisciplined way, he cannot help saying angrily: "Respected Committee! There is no fault or disease! I did nothing but I behaved spontaneously and according to my nature! Don't I have the right to behave in a spontaneous way according to my nature?" The representative of the System answered:

13. According to Joan Slonczewski and Michael Levy, since the publication of Rachel Carson's Silent Spring (1962), and the awakening of the environmental movement, SF writers have confronted the dilemma of the effects of human beings on our biosphere. The starkest cases have been in the genre of post-apocalyptic novels, such as Nevil Shute's On the Beach (1957), or Russell Hoban's Riddley Walker (1980), or in novels predicting impending environmental collapse, such as David Brin's Earth (1990), and Dennis Danvers's The Fourth World (2000). In other cases, environmental concern has led to large-scale depictions of entire planets and multiple societies grappling with the problem of 'terraforming' [literally, "Earth-shaping", E. A.], that is, how much change, intended or otherwise, to inflict on a biosphere to bend it to human needs (Slonczewski and Levy, 2003: 183).

14. We find images and descriptions similar to this in the novel This Perfect Day (1970) by Ira Levin, in which the world is managed by a central computer called UniComp which has been programmed to keep every single human on the surface of the earth in check. People are continually drugged by means of monthly treatments (delivered via transdermal spray or jet injector) so that they will remain satisfied and cooperative "Family members". They are told where to live, when to eat, whom to marry, when to reproduce, and for which job they will be trained. See also The Dictionary of Science Fiction Places (1999) by Brian Stableford. The dictionary includes brief descriptions of imaginary places devised by SF writers, from H. G. Wells through to such recent authors as Mary Doria Russell (Stableford, 1999). 
"This is not a spontaneous behavior, Sir! It is a whim, and whims are against discipline! It is getting out of discipline. Anything that gets out of control threatens the public order at the bottom. Therefore, we should initiate an investigation to find out the motives of this whim and treat it so that it will not be repeated. The whim leaves a feeling of pleasure, and pleasure tempts to repeat it."

At this moment, Homo shouts:-

"Gentlemen! You are killing the creative feelings in the citizens. You are killing individual freedom within the idea of discipline! You stop whims, and prevent divine human imagination from wild soaring, from which genius is born!"

The representative of the System replies to Homo's protest saying: "All the required geniuses for the production plan for the Globe are totally born by request at the plants." 15

Homo shouts in challenge:-

"These are false geniuses, different, artificial, cold and inhuman geniuses. This laboratory mating that you perform in tubes between the distinctive hereditary elements produces inhuman creatures, these are inhuman actions, flesh and blood are essential, humanity is essential." (Mūsā, 1987: 38-42) ${ }^{16}$

The dialogue reveals Homo's rebellious personality resisting the mechanical System. Homo wishes that Man would return to his nature and the spontaneity with which he was born. Homo sees that the mechanical System kills this nature and turns Man into a machine that has no feelings and cannot think on its own. This System makes Man a performer of orders who does not object to or debate them. Scientific and technological progress provided Man with all the facilities that he needed for his comfort, but he tied a rope round his neck instead of enhancing his enjoyment of life.

Nevertheless, the author says, even if a utopian society is attained, Man will remain Man, because neither social justice nor individual freedom nor scientific progress can reach basic human individuality and kill it. This individuality enables him to worry, to be tense, to refuse and object, to look anxious, to yearn for something lost, and to dream.

The question that arises here is "What makes Homo and people like him stop their habitual current of life, despite this beautiful utopia?" The answer is related to the issue of paradox. The citizen in this robot-like society does not suffer from problems related to affairs of livelihood, and what is more important is that he enjoys real freedom. However, this freedom is defined by the System, and not by Homo and people like him who see this superimposed freedom as mechanical, artificial and fake. They view it as slavery in disguise, which kills the nature of human beings and their spontaneity. Homo is a symbol of the paradox. He shouts during the investigation: "I am not defending losing issues, I am defending my freedom." The representative of the system replies:

"To be accurate, you are not defending freedom, but backwardness, because you are defending a mess. You consider your spontaneous behavior a kind of freedom, and this is a big mistake, and it is our duty to correct it for you. It impossible for us to keep you here against your will, and you can get up and go immediately having all your freedom with you, and go away wherever you like in the world and no one will stop you or ask you any question." (Mūsā, 1987: 42-43)

Homo's deviation from his daily schedule is considered a deviation from the programmed mechanical system, which defines for everyone their place and timetable until they become the slaves of this System. Homo sees that his crisis in essence is a human crisis that stems from his living and being imprisoned within a transparent plastic egg that hangs in the sky, despite the mechanical facilities and luxurious life that this egg contains. The incarceration is not

15. According to Joan Slonczewski and Michael Levy, as physical and chemical imaging techniques have revealed the brain's inner workings, SF writers have gone beyond the largely discredited notion of Extrasensory Perception (ESP) to explore the biochemical frontiers of the brain. For example, Nancy Kress's Beggars in Spain (1993) and its sequels depict a class of humans genetically modified for brain function without sleep. Orson Scott Card in Xenocide (1991) and Vernor Vinge in A Deepness in the Sky (1999) consider the possibility of altering the human brain to induce obsessive compulsive disorder, creating highly talented workers who think only of the job at hand (Slonczewski and Levy, 2003: 176-177).

16. On genetic engineering in SF, see Slonczewski and Levy, 2003: 180-181. 
only external, but internal as well. Whenever he looks at the horizon, obscured by the transparent plastic, a call from inside him rises, demanding to be let out of his pampered prison to live a natural life on the deserted land.

Homo, Proof and the rest of the rebels insist on going out of their mechanical country back to nature. There, the group confronts horrors and risks, where the fight to live is severe, and only the powerful survive, and where gigantic trees eat living creatures. Zebras attack the cars of the group and the number of victims increases. On the third day, Homo decides to return, and he returns to his mechanical country. He stands days in front of the gate calling and crying, but no one answers his calls. Thus, Homo's departure from his place and programmed lifestyle to go back to nature leads to his tragedy. The tragedy of Man in this new age lies in his attempt to get out of the programmed system. Therefore, Man has to accept this slavery; otherwise, it will overcome him.

The human being in this society has to perform without thinking, because thinking is not required. Everything is arranged by the machines. Homo's exit from the programmed System of his country is similar to some extent to Adam's leaving Paradise, because Homo goes out of the honeymoon era or Man's Garden of Eden, which is hung in the sky. In the end, when he tries to behave consciously and through persuasion, and decides to return to his utopian city, it is too late and the curse takes effect on him. He is doomed to eternal expulsion from the city/Garden of Eden (al-Jayyār, 1987: 75-99; Raḍwān, 1987; 'Abdullāh, 1989; 'īd, 1985; Mūsā, 1987: 40, 52, 214-228).

\section{Nature:-}

It is possible to consider nature as an indicator of the character's external and internal characteristics. Jean-Paul Sartre (1986: 54-55) says that natural scenes exist in literary works in order to reflect the psychological conditions of the characters. Others (see al-Salīmiyya, 2013; al-Qusanținnī, 1995: 125) see that the storm, cold, darkness, sun, sky, and earth together share in drawing the psychological conditions of the characters and reflecting their aspirations, frustrations and disappointments. Joseph Ewen (1993: 107-108) believes that the entrance of the character into a new place creates a symbolic or analogous relationship between the character and the place. The meeting between the character and place is likely to show similar or contradictory qualities of each side. In these situations, the writer also intends to point out the different fluctuations in the character's temper.

Nature plays a significant role in the structure of the characters of the novel al-Sayyid min Haql al-Sabanik and highlights their opposition to the System due to its artificial nature. The novel draws unfamiliar forms to depict a virtual life. ${ }^{17}$ The novel does not consider it enough to draw the borders of these forms, but also describes many mechanical inventions in order to excite the human imagination. These inventions can be seen as a background painting of the place in which the events take place.

The first of these strange images is called 'The New World' or 'The Greater Plastic Egg', now hanging in space, and all humans left on earth now live in it. ${ }^{18}$ There is an optic cultivation field that produces vast quantities of spinach, a capsule car, and an air-train. We also see images of hospitals where people go to enjoy the experience of diseases of ancient cultures, and a lab wedding by tubes, chemical food, energy production from solar light, the melting of thick clouds by radiation apparatuses, an electronic brain that knows everything, machines that invent and develop themselves by themselves, satellites, spying satellites, and other imaginary images of a mechanical society.

As a result of atomic and hydrogen explosions in the first electronic war, radiation and terrible chemical poisons have covered the earth. The features of certain areas have changed so much that their nature changed completely. The solid sands of certain deserts have become so fragile that they are unable to bear a mosquito without swallowing it. The rocky bottoms of certain oceans and seas have disintegrated, fallen to pieces and melted into their sands or their sands have climbed out of the water like clay fountains and the water has become a dough of loose silt in which

17. For more details about rockets, spaceships, space habitats, virtual environments in SF, see Jones, 2003: 164-166

18. Similar descriptions appear in the novel We (1993) by Evgenii Zamiatin. See also the novel The City and the Stars (1956) by Arthur C. Clarke. The novel takes place one billion years in the future, in the city of Diaspar. By this time, the Earth is so old that the oceans have gone and humanity has all but left. As far as the people of Diaspar know, theirs is the only city left on the planet. The city of Diaspar is completely enclosed. Critics note that this method is repeatedly employed in a number of novels that deal with the form of life on Planet Earth in the future. See: 'id 1985: 226. Note that the theme of building up isolated cities to escape from wars, dangers and catastrophes is repeatedly mentioned in Arabic SF novels. See, for example: 'Awālim min al-'Amsākh (1977) by Țālib Imrān and Sukkān al- 'àlam al-Thānī (1977) by Nihād Sharīf. 
strange clay animals, a result of the radioactivity that attacked their cells, swim. Radiation has mutated the DNA every species, without regard to gender or type. Some species have mixed, while others have become extinct. New types of creatures such as trees that feed on protein or animals with huge wings have appeared. ${ }^{19}$

Homo is a farmer in a spinach field, though he does not like spinach. He sees his daily life as mechanical, depressing, boring, programmed precisely and strictly by the System. He cannot deviate from his routine. Every day is the same, from the moment he gets up until he goes to bed. Homo decides to stop break the tedium. He wants to be able walk around freely, to run and jump and laugh and have fun, to give up his boring comfort that is about to freeze his bones. When he does what he wants to do, he finds himself in trouble that he did not expect. He is a member of a strict and disciplined society that shapes its members in a precise way, and does not tolerate exceptions. The individual in such a society has to perform and enjoy, not think, as thinking is not required, because the System controls everything. ${ }^{20}$ After Homo stops following his daily routine, he decides, together with a number of other members who join him, to stop living in a mechanical society, and go out to nature. Homo sees himself as a machine following a boring routine. He begins to hear within himself a voice calling him to wake up and rebel, to go down to Planet Earth, and restore the simple life on Earth. ${ }^{21} \mathrm{He}$ is summoned into the investigation room.

During the investigation, the characters of Homo and his colleague, Proof, are revealed. The investigation starts with Homo, who accuses the mechanical System of killing feelings and stifling personal freedom. He accuses the System of being one that prevents impulses, hinders imagination, and kills genius. The investigator assures him that he is free to choose his fate because they respect the individual's freedom and his humanity. Proof heads the opposition group, which loves nature and wants to protect it. Proof argues that Homo's breaking away from the routine of his daily life does not stem from the crisis of freedom, but a crisis of beauty. After the System broke with nature, life became void of beauty and spontaneity. It now exists only in the archives of ancient movies. Natural beauty has been replaced by artificial gardens that are covered with thick transparent plastic, whose flowers are made of crystal, whose trees are programmed artificial ones that behave like living trees, and from time to time, one of its leaves fall,

19. Mutation is an enduring theme in SF. Mutation leads to evolution, a principle of central importance to SF. The idea that some key mutation might cause sudden evolutionary change, that entire new species might come into existence practically overnight, has always been popular. John Taine's evolutionary fantasies, The Iron Star 1930 and The Seeds of Life 1931, were important early examples of this idea. Recently, with the increasingly powerful arguments being promulgated by Stephen J. Gould and others for the concept of punctuated evolution, the theory that some changes can occur in a very short time frame, has gained renewed interest and has been used by a number of SF writers. Current examples include Bear's Darwin's Radio (1999) and Greg Egan's Teranesia (1999) (Slonczewski and Levy, 2003: 177- 178).

20. It seems that the author is criticizing the 1980s Egyptian regime in particular and the Arab regimes in general. The Egyptian regime during that period was an absolute regime; President Ḥusnī Mubārak and his men held all government authority exclusively. This regime dictated, imposed and gave orders with no opposition or resistance by the people. The regime did not allow other political parties or any opposition. People could not express opinions, introduce new thoughts or ideologies, or participate in governing. The regime did its best to suppress people's liberties, and keep the people ignorant. It also co-opted the sciences, media, and education to its policy, and ultimately, appropriated all the social, cultural and political aspects of life so that they served the interests of the regime.

21. The idea of rebellion against the Mechanical System is repeated in many SF novels such as 1984 (1949) by George Orwell, in which Winston Smith rebels against the mechanical system, which depends on cameras and televisions to spy on the behavior of every person. See also Ray Bradbury's novel Fahrenheit 451 (1953), in which Montage rebels against the firemen, the men of the authority, who roam the city looking for books to burn at 451 degrees Fahrenheit. In Arthur C. Clarke's novel, The City and the Stars (1956), Alvin lacks the natural instincts of other Diaspar citizens to remain within the city. He has something of the opposite, a desire to leave the city. 
in a sad imitation of living trees. ${ }^{22}$ Therefore, modern life has become devoid of beauty and the spontaneity of nature. $^{23}$ The individual has lost his feeling of belonging, and is unable to recognize himself and where he belongs.

Hearing Proof's explanation and analysis, Homo starts to translate his feelings into thoughts. He starts observing the long similar queues of workers, winding through the wide shadowed glass-roofed square to get on trains an expression of his feelings of being enslaved and part of a herd. When he fails to see the real sky, an image, millions of years old, crosses his mind. It is the image of mammals climbing trees and living in their branches, of multicolored glowing lights that float over the tree tops in the tropical jungles, revealing to the ancients, also living in serenity among the branches, a broad world of flowers, buds, insects and birds, and different colors, which are also a delicious meal. The more he looks at the horizon through the transparent plastic, the stronger the call within him to get out of the prison and return to real life and beautiful nature on the deserted land.

The System spares no effort to replace the earthly nature with one with which everyone can harmonize. The System is busy producing mechanical tools to achieve abundant justice, but this requires mechanical increase at the expense of the natural area. Therefore, the representatives of the System try to deal with Homo in two ways. First, they ask his wife, Layālī, for assistance to bring him back to his programmed track. Second, they treat him chemically by injecting some kind of chemical compound into the cells of his nervous system. Homo, however, refuses the suggestion of the System's representatives, because they deprive men of spontaneity and the spirit of adventure, which led the earliest humans to discover fire and settle the plains. Because of this innate ability, humans, though still a young species, were saved from the hardship of the glacial period.

Proof, however, sees that the representatives of the System control everything, including themselves. Their intelligence is devoid of spontaneity and emotions guided by scientific laws created by machines. This intelligence has become a new instinct that the System's representatives try to implant in humans whose ancient instincts they try to uproot. It is a scientific intelligence deprived of emotions and has become fanaticism. ${ }^{24}$ Therefore, Proof decides to confront the representatives of the System before they lead human kind to an inevitable catastrophe that is embodied in overturning the natural laws that are inherent in human beings.

Proof also sees that Homo and his companions, by virtue of the natural and spontaneous spirit that shines inside them, realize the catastrophe towards which humanity is drifting. When they stop following their designed and programmed daily life, they are in fact responding to inner alarms that are similar to spontaneous inspiration that the march is wrong and must be stopped. ${ }^{25}$ Therefore, a revolution against the System must take place, and after this, the people should return to using their natural human abilities, develop natural human relations, and enable natural

22. Patrick Murphy sees that much of SF is set in manufactured environments and some in natural environments, including the human body. Sometimes this environment becomes a nonhuman or non-individuated sentient character, such as the sentience-evolved planet in John Brunner's The Dramaturges of Yan (1972) or the 'biomechanoid' ship in Farscape (1999-2003), but generally, it remains a backdrop (Murphy, 2009: 374).

23. Compare with the novel Breakfast of Champions (1973) by Kurt Vonnegut Jr. The novel describes a mechanical society that is void of spirituality and beauty.

24. According to Andy Sawyer, following the irrevocable changes of the American and French Revolutions, Darwinism and Marxism suggested that the flow of events moves beyond the present to a mysterious, often ineffable future. Just as the $19^{\text {th }}$ century historical novel made the past into an imaginative territory in which to examine what we have become, so stories of the future increasingly turned to the exploration of the possible and the hopes and fears of what we might become (Sawyer, 2009: 488).

25. Michael Cooperson believes that the time-travel genre in Arabic is as old as its English-language counterpart. During the 1880s and 1890s, time-travel novels appeared almost simultaneously in Egypt, Britain, and the United States. The most recent and most ambitious Arabic time-travel novel is Khayrī Shalabī's Riḥlāt alTurshajī al-Halwajī (1991), which plunges gleefully into contradictions of past and present. Ironically, this novel offers an image of Egyptian history by confronting it with an alternate version of itself from another period. Moreover, Cooperson sees that pessimistically, we can read the novel as an expression of the deep fragmentation of the Egyptian postcolonial identity. The novel subverts the notion of linear time, a subversion that appears to arise from a sense that Egypt has not only failed to change in accordance with Western notions of progress and development, but has also failed to retain its own dynamic identity (Cooperson, 1998: 179-183). 
delivery of natural human beings. Then, with a clean conscience, they can return to their motherland, rediscover it and care for its wounds so that it can once again become the Garden of Eden. ${ }^{26}$

Some critics (see al-Jayyār, 1984; Khaḍr, 2001: 103; Raḍwān, 1987) believe that Homo’s tragedy stems from his being characterized by two main traits. First is the inner call that awakes his feelings and directs them to a purpose. This call moves him onto a road that leads to his tragic end. Answering the call sends him out of mechanical society, and throws him into a land of wild plants, moving trees, and animals that have lost their natural qualities due to their genic mutation, and as a result, human life in it, became impossible. Escape from it is impossible, and Homo helplessly cries for rescue, but there is no rescuer. Second is his desire to return to nature in its natural, unspoiled by civilization state. In the state of primitivism, human being abilities and strengths can be released; civilization hinders their development and limits their use. These capabilities are muscular, mental, and emotional powers that interact with the solid powers of nature to show the greatness of Man and his abilities, and change him from an ordinary creature into a great, active one that interacts with the world that surrounds him.

'Abdullāh (1989) and '⿳亠丷⿵冂丶 (1985) believe that any society, no matter which system it follows, must have some sort of conflict inside it. We are in confronted by a social system that seeks to progress against opposing powers that call for going backward. The novel addresses this issue, and its answer is that the defect in the era of progress lies in certain individuals who opt out of the System and seek to go back to nature. As the powers of progress, in the end, win the conflict, the triumph of the System's project becomes a historical inevitability, and the powers of backwardness retreat forever. If Homo describes his desire to return to nature and his spontaneous love as defense of his freedom, the System's representative rightly answers him, saying, "Returning means backwardness, and defending backwardness means defending chaos. Consequently, defending one's freedom in this case means defending backwardness" (Mūsā, 1987: 42-43).

Homo tries to resist the rational development of the System, and in doing so, suffers from confusion and anxiety. He attempts to deal with his problem in an emotional manner instead of facing it rationally. His fundamental problem lies in his unconscious surrender to emotions that no longer fit the place and time in which he lives. Homo continues in this way, pushed by unknown emotional powers towards his inevitable destructive fate. In the end, when he becomes aware of the reality around him, he tries to behave rationally, persuaded by his mind, and tried to returns to his utopian city. It is, however, too late, and he is sentenced to eternal exile from his earthly paradise, because he was not persuaded by a simple truth that the novel introduces: every nature has its own creatures, and every creature has his own specific climate. ${ }^{27}$

\section{Dialogue:-}

Dialogue is a very important techniques used in drawing the character in a novel. It is a valuable technique of narrative discourse that allows a character to express what goes on inside him or her and show his or her feelings, attitudes, opinions, and occupations in his or her words, tendencies, education, culture and tastes (Guellouz, 1992; Swīdan 2006: 134; al-'Amāmī, 2001; Qassūma, 2000: 212-235). Dialogue is considered an indicator of the characters' interest and the extent of their anxiety towards certain issues. It is an instrument for expressing differences of visions and disagreements about attitudes (Husayn 1988: 69, 85-86, 155; Samāḥa, 1999: 36-37; Swīdan, 2006: 134). In places in the novel, the words of Homo reflect his fear and anxiety about the exposure of human intelligence to danger, and consequently to the division of society into two groups: a clever dominating group and a less clever dominated group. This fear stems from the policies of the mechanical system

The dialogue that takes place between Homo and the System's representatives represents Homo's denial of the idea of 'Molding' in his programmed society. Homo refuses to become a number because he sees what others do not see. The mechanical system, in his view, kills feelings, freedom, impulses, imagination and genius, and, produces at

26. Patrick Murphy believes that many nature-oriented SF novels set on Earth use a post-apocalyptic situation to argue for a return to nature. Relying on a tremendous reduction of the human population, they are often not useful for readers who want to think their way through looming environmental crises. When virulently antitechnological, they promote a neo-primitive way of life, as with Jean Hegland's Into the Forest (1996), but when less intensely anti-technological they can encourage consideration of alternative structures for civilization, such as Ernest Callenbach's Ecotopia (1975) and Scott Russell Sanders's Terrarium (1985) (Murphy, 2009: 376).

27. Homo's departure from the city, after the representatives of the System agree to this, is to some extent similar to the departure of the hero (Alvin) in the novel The City and the Stars (1956) by Arthur C. Clarke. 
request, in its factories, different geniuses that are creative in sciences, arts, geometry and sport. Therefore, these are fake, artificial and non-human geniuses. ${ }^{28}$

The dialogue also conveys the conflict between the programmed (robotic) man and the programmed machine, on the one hand, and the rebelling man and the social System, on the other. Homo tries to withdraw from the mechanical social System that is precisely programmed and under complete control. However, his deviation becomes his tragedy, which lies in his being a representative of the first human rebellion against the mechanized system. Therefore, he had better accept this slavery; otherwise, it will subjugate him. The individual in this society has to listen, obey and perform without thinking. The machine thinks and decides for him. ${ }^{29}$ Human feelings have turned into backward subjects, as the representative of the System says: "I smell in these words the smell of a psychological backward deviation". Despite the selection of justifications for the crime and private caprices, discipline is the slogan of this mechanical society.

Layālī, Homo's wife, at the request of the representatives of the System, tries to persuade her husband to retreat from his rebellion and continue living with her, but Homo replies to her saying:

"I thought a lot when we were in the hall, in fact, I consulted the Comprehensive Mind, who knows everything and can answer every question, and advised me to stay but I find myself unable to be at odds with the whole group for whom I have become a symbol. Didn't you hear all that in your ears, Layālī? I have become their symbol and model. How can I give them up now?” (Mūsā, 1987: 207-208).

These words reveal Homo's rebellious character, a character that has a powerful will and determination, and is careless to its own fate, even if it is tragic. Through Homo's words, the writer emphasizes that Homo is a symbol, rather than an individual, a symbol of the man who Sins, and it is time for him to make amends for his sins. Homo enters the hall - the temple that houses the Comprehensive Electronic Brain, which knows everything and is able to answer all questions. ${ }^{30}$ Homo feels he is a little man in front of this giant. When Homo asks him existential questions, this electronic brain gives him strange answers that turn Homo into a symbol rather than a human being. When Homo asks him: "Who am I?", the Electronic Brain answers:

"You are the one who killed your brother Abel, and betrayed your father, you even made him loose his mind, and buried your sister alive in the sands of the desert when she was born. It is time for you to atone for all your old sins."

Homo shouts exhaustedly: "Why me in particular?" The Mind answers him:

"You are not an individual, and you have never been an individual. Even in those cultures in which you behaved like an individual, and spread individualism around you, and polluted your history with blood and destruction, you were not doing that out of your individualism, but by inspiration of instinct of the old group that you belonged to for millions of years."

And when Homo asks the Electronic Brain to guide him to the solution of his impasse, the Mind replies:

28. Compare with the novel Brave New World (1931) by Aldous Huxley.

29. Patrick Murphy believes that we can define Ecology as an existence: A natural system that undergoes or can undergo both auto dynamic change and externally induced change and encompasses multiple interactive environments (local ecosystems). This system includes actants considered to have agency, in the sense that we usually reserve for human beings. In the case of SF, however, the agency may be limited to biological entities or determined on the basis of manifestations of sentient behavior, thereby potentially including artificial persons and intelligent machines (Murphy, 2009: 347).

30. The same situations are repeated in many SF novels and short stories, e.g., in the short story Hub fi al-Qarn alWähid wal- 'Ishrīn (1987) by Ra' ūf Wasfì. The hero turns to the Electronic Brain to consult him on solutions to his love for his colleague. This similarity in approaching the Electronic Brain, which knows everything, is an accepted approach in the age of science, where the Electronic Brain controls the people and moves all the fields of life. At the same time, it represents the comprehensive knowledge of the citizens. The Electronic Brain appears to be a replacement for the relationship of fathers or friends, to whom modern man looks for help with problems that he faces. Some critics maintain that using the term 'Temple' to refer to the area of the Comprehensive Electronic Brain in the novel of al-Sayyid min Haql al-Sabānikh, is an expression of the people's devotion to the importance of the Electronic Brain; see 'id, 1985: 228, 236. 
"Catch your heart, Homo, I see you are weakening. You are the one who taught me how to think, how do you ask me to tell you how to think? The present is the time of final salvation and escape from the old fear and old sins." (Mūsā, 1987: 185-191)

The writer manages to reveal many different facets of Homo's internal struggle. The writer is able to introduce these sides through his meeting with the Investigation Committee, through discussions with his friends, David and Proof and his wife Layālī, through the debates at the entertainment places, and through his discussion of his condition by himself. One of the aspects is the issue of his sudden attention to his loss of will.

Homo says to his friend, David: "I imagine that we don't use our will anymore, and the modern man abandons himself to an easy tasty life like a piece of wood that flows with water current, without will." His friend says:

"Do you want to say that the moment of separation that overcame you is a result of the sudden attention of the loss of will, and those other similar conditions are also conditions that overcome other people when they realize suddenly that they just live, and they only do what has to be done?"

Homo answers:-

"Yes, Yes. This is the exact expression, to do what has to be done, and what is expected and habitual to be done. That is the question, exactly. This means that the contemporary Man has been deprived of his intuitive spontaneity and the spirit of adventure. I don't know David, but I feel that there must always be a goal and a will with which we seek our goal. The goal of our ancient predecessors was food and now this goal has been fully achieved, and every human can eat what he likes at any time without any effort or thinking. What concerns me is that during our involvement in achieving this goal, we have forgotten that it is no more a goal in itself, and that it is a medium to continue our life, and by that mistaken concept, we have obliterated the will to develop spontaneously in the human brain. Human beings have become similar to a really worrying degree, David, identical copies in clothes, food, thinking, and daily life performance. All the brains have become captives and are drowning in this cultural and informative flood that is pushed into them by the media equipment and central education. All of them think and behave according to the required way." (Mūsā, 1987: 115-116)

This dialogue reveals Homo's desire for Man's return to nature and spontaneity, to the time when Man possessed his own will that allowed him to reach and achieve his goals. Homo's problem lies in his search for a goal in life in the era of technology, which is an era that erases the character of the individual and merges it into the group or community. It is an era of obliteration of one's particularities and individualism, and turns every person into a slave to the machine and the System. Homo's opinions are in line with the opinions of the General Inspector in Dostoyevsky's novel The Brothers Karamazov (2002). He sees that the secret of human existence and its justification are not in the will to live, but in the need to know the cause that calls the human being to live. If the human being is not sure about the goal of his life, he will not agree to live in this world, and will prefer to destroy himself even if he possesses bread all the time. Others (see ‘id, 1985: 233) maintain that Homo's statements reflect the worry that exists among some thinkers of the future society. It is a society that includes two categories of people. First, there are automatic people without a will, who can implement a primitive limited operation, and anything that goes beyond the borders of this operation is a burden that exceeds their capabilities. Second, there is a small group of administrative technicians.

The System, through the words of David, shows that this is necessary and believes that uniformity of performance is the law of nature:

"Mister Homo, the System that has been achieved for us leads the human kind in its natural path! We managed to excel and outdo all species that were with us on the Earth when we started to contemplate in nature that surrounds us and understand some of its rules, and continued our development till we managed to know nearly everything about the planet that we live on.” (Mūsā, 1987: 118)

Some philosophers (see Winewood Reade, quoted in '1̄d, 1985: 233-232, and René Descartes, 2008) expressed the same views in their argument that we are able to control nature by complying with its rules. In order to obey its rules, we have first to know the essence of these rules. When we become sure by science about the way nature works, we will be able to assume its role and do its job by ourselves. Knowledge of the rules that natural phenomena 
obey lead to knowledge of their components and the relations between what exists between them, and this allows us to exploit it and employ it to achieve Man's goals and interests. In this way, Man can turn nature to his service, to become its master, and its owner.

Homo says to his friend, David: "We are sitting between the branches of the era of honey, and our minds are relaxed in a delicious contemplative laziness, while our hot and cold meals come to us through tubes." and David replies: "But it is certain that there are brains that are working to run life." Homo answers with sudden pain: "There are brains that actually do so, but they are not my mind or yours." David says:

"The System tries to solve an actual complex problem. It dominates, and protects and provides happy life for every individual from birth to death through an organized collective behavior, and through preserving all the basic traits that make man a human being."

Homo says vehemently: "Look, the first who is exposed to danger in such system is the human intelligence." David says: "Those who occupy the leadership positions are highly intelligent." Homo said:

"Yes, but in return, all those who do not occupy leadership positions are required to be easygoing and less intelligent, and have a skill without emotion, a skill of instinctive performance, and I am afraid that we might have reached in our mental development to a dead end." (Mūsā, 1987: 111-113)

Proof considers the intelligence of the representatives of the System or the Technocrats to be a kind of intelligence that is void of spontaneity. It is an intelligence that is guided by scientific rules that are invented by machines. This sort of intelligence has become a new instinct that the System tries to implant in humans after uprooting their old instincts. In fact, this type of scientific intelligence that is devoid of feelings has become a type of fanaticism. Proof considers the people in charge of the System to be criminals because they seek to turn the individuals into a herd in the greater machine, and in this way, the System can take everything and give everything; it can take life from nature and the soul from the human being.

Proof accuses the System of killing Man's individual aptitudes by the domination of the mechanical slaves, who have actually become the masters, and consequently, Man has become a slave to the machine. Proof sees that the first social revolution in history was the revolution of the slaves against their masters. He wants the revolution now be the revolution of Man against the mechanical masters. In Proof's point of view, the System prevents the development of the mind and human intelligence. The System has abolished instincts without noticing the commensurate decline in the level of human intelligence as a result of the mastery of the instrument's mechanical logic. In Proof's view, the instincts should be preserved in order to preserve the human race. Humans' feelings of happiness and pleasure should be kept, especially the maternal happiness of women who should not be deprived of this instinctive feeling (Mūsā, 1987: 156-181).

The expected confrontation of the vast scientific and technological development in the future led to the emergence of three trends. The supporters of the first trend argue that this scientific development will create machines with abilities that will grow continuously and a time will come when these machines will get out of control. Man will no longer have authority over them and they will turn against him, and will probably destroy him or turn him into a slave. These machines will probably gain a certain type of self-awareness, and when they realize that their power is greater than Man's, they will probably get rid of him. The supporters of this trend, including Aldous Huxley, argue that the individual in the modern era has lost his political freedom because of scientific development. Men have invented weapons and lost their mental independence. They have also lost their economic freedom due to centralization of industries. Leo Tolstoy warned against this. He argued that if the social system is unjust, and the power is in the hands of a few people, who exploit others and persecute them, the result of any scientific progress will be reinforcement of this exploitation and persecution or even dictatorship.

The supporters of the second trend argue that the machine will emancipate the human being from all kinds of slavery, and will assist him on his way to the future about which he dreams. They imagine that technological progress is a guarantee against all types of injustice and oppression, whether it is nature's oppression of Man or Man's oppression of men. This development will achieve abundance for human beings and exempt them from having to make any effort. 
The supporters of the third trend argue that machines, no matter how much or how high they develop and how intelligent they become, will constantly remain an obedient instrument in service of man (Huxley, 1947; Zakariyyā, 2004: 139-140).

Regarding the role of SF in the future, there is an optimistic trend represented by Ado Barbaro (Barbaro 2013, Interview with Ada Barbaro) who believes that SF creates spaces where the reader can find a confirmation of his or her own fears about progress, which can be frightening, but also lifesaving. It gives us the chance to see how things can made in another way, how conflicts that are difficult to manage can be resolved, how we can handle the relationship with our "Other," namely the alien. The human in the beginning of these kinds of novels is always cautious in relating to the alien because he is scared, and it may be that these authors want to show us something they have experienced, hence the relationship with the West, the need to overthrow taboos and clichés in the writings of Arab SF authors. In the SF worlds, there are relationships that do not exist in reality. We are offered the possibilities to imagine future and utopian worlds and societies ruled by justice and good governance.

In addition, Barbaro sees that SF represents a refuge for the reader, instead of being related to progress. This reader perhaps lives in a reality where a changing society can overwhelm him or her, but in the end, he or she knows that the scientific developments will lead him or her to a better world. SF also helps the reader to look back on past mistakes because progress is seductive, but makes you do everything in your power in order to be successful. It brings your values into question. So often, when SF novels describe future dehumanized societies, where humans have lost their purest feelings and values, the reader is forced to think about what he or she has done in the past and what to do to avoid making the same mistakes all over again.

\section{Conclusion:-}

The author under discussion attempts to construct a utopia, where the General System that runs life on the Planet Earth consists of a group of technocrats, who are not politicians or rulers. Thanks to their expertise, these people have a just social system, where all the products and fruit of food, warmth, housing, art and education are distributed in a just and fair way. ${ }^{31}$ The System operates according to a general plan through a vision that aims to achieve rational and perfect human beings. This system seems to be like the one suggested by H. G. Wells, who believed that the new brain is the scientific view of life and existence, the mind that rejects every view of life that is based on religion, or supernatural theories. It is the mind that wishes that the scientific spirit will prevail, a spirit that issues judgments after patient deliberation, with no prejudice and bias, and insists on opening up all kinds of knowledge and beliefs for discussion. This scientific spirit will enable humanity to take its fate and future into its own hands.

\section{References:-}

1. 'Abdullāh, 'Abd al-Badī'. (1989). Ma'sāt al-Mutamarrid Homo fi Riwāyat Șabrī Mūsā al-Sayyid min Haql alSabānikh. 'Ibdā', 2, 22-26.

2. 'Adham, 'Alī. (1970). 'Iwān min 'Adab al-Gharb. Cairo: Dār al-Hilāl.

3. al- 'Amāmī, Muḥammad Najīb. (2001). al-Rāwī fi al-Sard al-'Arabī al-Mu 'āṣir. Șafāqis: Dār Muhammad 'Alī al-Thānī li-Nashr wa-Tawzī' \& Sūsa: Kulliyyat al-' AAdāb wa-l- 'Ulūm al-'Insāniyya.

4. al-Bārd̄̄, Muḥammad. (1993). al-Riwāya al-'Arabiyya wa-l-Hadātha. Vol. 1. al-Lāẓiqiyya: Dār al-Ḥiwār liNashr wa-Tawzi'.

5. al-Jayyār, Midḥat. (1984). Mushkilat al-Hadātha fi Riwāyat al-Khayāl al- 'Ilmī. Fușūl 4(4), 180-184.

6. al-Jayyār, Midḥat. (1987). Thulāthiyyat al-'Insān: Dirāsa fi Riwāyāt Șabrī Mūsā. Cairo: al-Hay'a al-Mișriyya al- 'Āmma li-l-Kitāb.

7. al-Salīmiyya, Munā Bint Hibrās. (2013). al-Ṭabīa fi al-Riwāya al- 'Umāniyya. 'Umān: Bayt al-Gashām liNashr wa-Tarjama.

8. al-Qāsim, Nabīh. (2005). Al-Fan al-Riwā' '̄ 'inda 'Abd al-Raḥmān Munīf: al-Makān, al-Zamān, Al-Shakhṣiyya. Kufr Kari : Dār al-Hudā li-Ṭibā‘a wa-Nashr.

9. al-Qusanțīnī, Najwā al-Rayāḥ̄. (1995). al-Hilm wa-l-Hazīma fi Riwāyāt 'Abd al-Raḥmān Munīf. Tūnis: Kulliyyat al- 'Ulūm al-' Insāniyya wa-l-' Ijtimā' iyya.

10. Bachlard, Gaston. (1994). The Poetics of Space. Trans. Maria Jolas. Boston: Beacon Press.

31. For more details about the relationships between SF and utopian novels, see Freedman, 2000: 62-85; Wegner, 2014. 
11. Baḥrāwī, Hasan. (2009). Bunyat al-Shakl al-Riwā' '̄: al-Faḍà', al-Zaman, al-Shakhṣiyya. Beirut \& al-Dār alBayḍā' : al-Markiz al-Thaqāfī al-' Arabī.

12. Barbaro, Ada.(2013). La fantascienza nella letteratura araba. Roma: Carocci.

13. Barbaro, Ada. (2013). Interview with Ada Barbaro: Science Fiction in Arabic: 'It Was Not Born All of a Sudden.' Retrieved from http://arablit.org/2013/09/30/science-fiction-in-arabic-it-was-not-born-all-of-a-sudden/

14. Barthes, Roland. (1074). S/Z. Trans. Richard Miller. New York: Hill and Wang.

15. Broderick, Damien. (1995). Reading by Starlight: Postmodern Science Fiction. London and New York: Routledge.

16. Butler, Andrew M. (2014). Futurology. In Rob Latham (Ed.), The Oxford handbook of science fiction (pp. 513523). Oxford: Oxford University Press.

17. Cooperson, Michael. (1998). Remembering the Future: Arabic Time-Travel Literature. Edebiyât 8(2), $171-189$.

18. Descartes, René. (2008). A Discourse on the Method. 1st ed. Oxford: Oxford University Press.

19. Docherty, Thomas. (1983). Reading (Absent) Character: Towards A Theory of Characterization in Fiction. Oxford: Oxford University Press.

20. Dostoevsky, Fyodor. (2002). The Brothers Karamazov. Trans. Richard Pevear and Larissa Volokhonsky. New York: Farrar, Straus and Giroux.

21. Ewen, Joseph. (1993). Character in Narrative. Tel Aviv: Poalim.

22. Fokkema, Aleid. (1991). Postmodern Characters: A Study of Characterization in British and American Postmodern Fiction. Amsterdam- Atlanta, GA: Rodopi.

23. Freedman, Carl. (2000). Critical Theory and Science Fiction. Middletown, CT: Wesleyan University Press.

24. Garvey, James. (1978). Characterization in Narrative. Poetics, 7, 63-78.

25. Guellouz, Suzanne. (1992). Le dialogue. Paris: Presses Universitaires de France.

26. Hamdāwī, Jamīl. (2010). Sīmyā' 'Ism al-'Alam al-Shakhṣī fì al-Riwāya al-'Arabiyya. al-Muthaqaf, 1581, Retrieved from http://almothaqaf.com/index.php/aqlam2009/40322.html.

27. Hamon, Philippe. (1972). Pour un statut sémiologique du personage. Littérature, 6, 86-110.

28. Husayn, Hamd̄̄. (1988). Al-Shakhșiyya al-Riwā'iyya 'inda Maḥmūd Taymūr Bayna al-Nazariyya wa-Tațbīq. Cairo: Dār al-Thaqāfa li-Nashr wa-Tawzī‘.

29. Huxley, Aldous. (1947). Science, Liberty \& Peace. London: Chatto \& Windus.

30. 'īd, Husayn. (1985). Qirā'a fi Riwāyat Al-Sayyid min Haql al-Sabānikh 'Aw Yūtūbyā 'Asr al- 'Ilm. Fuṣūl, 6(1), 223-236.

31. James, Edward. (2003). Utopias and anti-utopias. In Edwards James and Farah Mendlesohn (Eds.), The Cambridge Companion to Science Fiction (219-229). Cambridge: Cambridge University Press.

32. Jones, Gwyneth. (2003). The Icons of Science Fiction. In Edwards James and Farah Mendlesohn (Eds.), The Cambridge Companion to Science Fiction (163-173). Cambridge: Cambridge University Press.

33. Khaụr, Mahā Maẓlūm. (2001). Binā' Riwāyat al-Khayāl al- 'ilmō fi al-'Adab al-Mișrī al-Mu 'ạșir. Cairo: Mața' at al-' ūfist al-Hadītha.

34. Lotman, Jurij. (1977). The Structure of Artistic Text. Trans. Ronald Vroon. Michigan: University of Michigan.

35. Maḥmūd, Maḥmūd. (1983). al-Khayāl al- 'Ilmī: 'Ithāra li-l-'Insān 'Am 'Iqtiham Limustaqbalihi?, al- 'Arabī, 294, 131-132.

36. Merrick, Helen. (2003). Gender in Science Fiction. In Edwards James and Farah Mendlesohn (Eds.), The Cambridge Companion to Science Fiction (241-252). Cambridge: Cambridge University Press.

37. Mousoutzanis, Aris. (2009). Apocalyptic SF. In Mark Bould, Andrew M. Butler, Adam Roberts, and Sherryl Vint (Eds.), The Routledge Companion to Science Fiction (458-462). London and New York: Routledge.

38. Murphy, Patrick D. (2009). Environmentalism. In Mark Bould, Andrew M. Butler, Adam Roberts, and Sherryl Vint (Eds.), The Routledge Companion to Science Fiction (373-381). London and New York: Routledge.

39. Mūsā, Șabrī. (1987). al-Sayyid min Haql al-Sabānikh. Cairo: al-Hay' a al-Mișriyya al- 'Āmma li-l-Kitāb.

40. Raḍ̂ān, Țal'at. (1987). Al-Sayyid min Haql al-Sabānikh: Ru'yā Mustaqbaliyya li-Riwā'̄ Șabrī Mūsā. 'ibdā', 7,15-20.

41. Roberts, Adam. (2000). Science Fiction. London and New York: Routledge.

42. Samāḥa, Firyal Kāmil. (1999). Rasm al-Shakhșiyya fi Riwāyāt Hannā Mīna. Beirut: al-Mu'assasa al- 'Arabiyya li-Dirāsāt wa-Nashr.

43. Sartre, Jean-Paul. (1986). What is Literature? Trans. Bernard Frechtman. London: Methuen.

44. Sawyer, Andy. (2009). Future History. In Mark Bould, Andrew M. Butler, Adam Roberts, and Sherryl Vint (Eds.), The Routledge Companion to Science Fiction (489-493). London and New York: Routledge.

45. Scholes, Robert, James Phelan and Robert Kellogg. (2006). The Nature of Narrative. Fortieth Anniversary Edition. New York: Oxford University Press. 
46. Seed, David. (2011). Science Fiction: A Very Short Introduction. New York, Oxford: Oxford University Press.

47. Siegel, Mark. (1980). Science-Fiction Characterization and TV's Battle for the Stars. Science Fiction Studies, 7(3), 270-277.

48. Slonczewski, Joan and Michael Levy. (2003). Science Fiction and the Life Sciences. In Edwards James and Farah Mendlesohn (Eds.), The Cambridge Companion to Science Fiction (174-185). Cambridge: Cambridge University Press.

49. Snir, Reuvin. (2002). Science Fiction in Arabic Literature: Translation, Adaptation, Original Writing and Canonization. Arabic Language \& Literature, 2, 209-229.

50. Snir, Reuvin. (2000). The Emergence of Science Fiction in Arabic Literature. Der Islam, 77(2), 263-285.

51. Stableford, Brian. (1999). The Dictionary of Science Fiction Places. Alaska, Palmer: Fireside Books.

52. Suvin, Darko. (1979). Metamorphoses of Science Fiction: On the Poetics and History of a Literary Genre. New Haven, CT: Yale University Press.

53. Swīdān, Sāmī. (2006). Al-Matāha wa-Tamwīh fi al-Riwāya al- 'Arabiyya. Beirut: Dār al-' Ādāb.

54. Qassūma, al-Ṣadiq. (2000). Tarā'iq Tahlīl al-Qissa. Tūnis: Dār al-Janūb li-Nashr.

55. Wegner, Phillip E. (2014). Utopianism. In Rob Latham (Ed.), The Oxford Handbook of Science Fiction (573584). Oxford: Oxford University Press.

56. Wolfe, Gary K. (1986). Critical Terms for Science Fiction and Fantasy: A Glossary and Guide to Scholarship. Westport, Connecticut: Greenwood Press.

57. Zakariyyā, Fu'ād. (2004). al-Tafkīr al- 'Ilmī. Alexandria: Dār al-Wafă' . 